ISSN 0258-7122

Bangladesh J. Agril. Res. 34(3) : 481-492, September 2009

\title{
EFFECT OF MANAGEMENT AND SEED RATE ON THE PERFORMANCE OF WHEAT VARIETIES WITH VARYING SEED SIZES
}

\author{
M.A.Z. SARKER ${ }^{1}$, P.K. MALAKER ${ }^{2}$, \\ M. BODRUZZAMAN ${ }^{3}$ AND N.C.D. BARMA ${ }^{4}$
}

\begin{abstract}
An experiment was conducted with three wheat varieties of varying seed sizes at five seed rates in medium and high management at Wheat Research Centre, Dinajpur during 2004-05 Rabi season to determine the appropriate seed rates for the varieties under different management practices. On an average, high management increased grain yield by $18.4 \%$, but the benefit-cost ratio (BCR) was higher in medium management. Higher grain yield was obtained from varieties Shatabdi (medium sized seed) and Prodip (large sized seed) compared to Sufi (small sized seed) in high management, whereas in medium management, all the varieties produced similar grain yield. Considering yield performance and BCR analysis, the seed rates of Sufi and Shatabdi might be 100 and $120 \mathrm{~kg} / \mathrm{ha}$, respectively, for both the managements. Seed rates of Prodip might be 120 and $140 \mathrm{~kg} /$ ha for medium and high management, respectively.
\end{abstract}

Key Words: Management, seed rate, seed size, variety.

\section{Introduction}

Wheat (Triticum aestivum L.) ranks second among the cereal crops grown in Bangladesh. In the early stages of wheat research in Bangladesh, Gaffer and Rahman (1979) used a spacing of $5 \mathrm{~cm}$ between seeds planted in rows $20 \mathrm{~cm}$ apart, which is impractical to some extent and seems to be costly. Subsequently, Ali (1980) found no significant difference in yield among the seed rates of 80 , 90,110 , and $120 \mathrm{~kg} / \mathrm{ha}$ in variety Sonalika, and recommended a seed rate of 80 $\mathrm{kg} / \mathrm{ha}$ for rainfed condition. Wheat area under irrigation is increasing and reached 56\% in 2002-03 crop season (Ahmed and Meisner, 1996; BBS, 2005). Now about $80 \%$ wheat area is sown under irrigated condition (Barma et al., 2006). A common seed rate of $120 \mathrm{~kg} / \mathrm{ha}$ has been recommended for all the varieties (Razzaque et al., 2000; Islam et al., 2004). However, farmers are using very high seed rate, sometimes even double of the recommendation for controlling weed as extra benefit (Saunders, 1990). But field observation revealed that farmers' yield is lower compared to research field due to higher plant density, shorter spike length and lower number of grains per spike.

\footnotetext{
${ }^{1-3}$ Wheat Research Centre, BARI, Nashipur, Dinajpur-5200, ${ }^{4}$ Regional Wheat Research Centre, BARI, Shyampur, Rajshahi-6212, Bangladesh.
} 
Recently, Wheat Research Centre (WRC) of Bangladesh Agricultural Research Institute (BARI) developed some modern varieties of wheat. Some of these have bolder grain and some have smaller grain size than the previously released varieties. It seems that for the varieties with larger seed size, higher seed rate may be required, whereas seed rate can be reduced for smaller seed size. Integrated nutrient and pest management may increase yield and require the optimum seed rate to be changed. It was found from WRC field that the varieties with bolder seed failed to produce the expected higher yield even with higher seed rate (WRC, 2004), and it has been suggested that high management may be an option to obtain the expected yield from those varieties. Therefore, it is essential to determine the seed rate of newly developed wheat varieties under contrasting management option for the maximum yield. The present experiment was undertaken to determine the appropriate seed rates of different wheat varieties having varying seed sizes under different management practices for higher grain yield.

\section{Materials and Method}

The experiment was conducted at the Research Farm of WRC, BARI, Dinajpur $\left(88^{\circ} 4 l^{\prime} \mathrm{E}\right.$ and $25^{\circ} 38^{\prime} \mathrm{N}$ ) during Rabi season of 2004-05. The soil was under the AEZ 1 (Old Himalayan Piedmont). The soil was sandy loam with pH 5.6 (Table 1). Soil organic matter and total $\mathrm{N}$ were lower than the critical level. Although available $\mathrm{P}$, exchangeable $\mathrm{K}$ and available $\mathrm{S}$ were higher than the critical level, the amount was very low for wheat.

Table 1. Soil nutrient status with critical level of experimental site of WRC, Dinajpur.

\begin{tabular}{l|l|l|l}
\hline \multicolumn{1}{c|}{ Nutrient/OM/pH } & $\begin{array}{c}\text { Amount } \\
\text { present }\end{array}$ & $\begin{array}{c}\text { Critical } \\
\text { level }\end{array}$ & Method of extraction \\
\hline Organic matter (\%) & 1.10 & 2.00 & Wet oxidation \\
Total N(\%) & 0.08 & 0.10 & Kjeldahl \\
Available P (ppm) & 12.40 & 8.00 & Modified Olsen \\
Exchangeable K (meq/100g soil) & 0.10 & 0.08 & $\mathrm{NH}_{4} \mathrm{OAc}$ \\
Available S (ppm) & 12.60 & 8.00 & $\begin{array}{l}\text { Calcium dihydrogen } \\
\text { phosphate }\end{array}$ \\
$\mathrm{pH}$ & 5.60 & - & - \\
\hline
\end{tabular}

The experiment was laid out in a split-split-plot design with three replications. Two managements: a) medium management-fertilizer nutrients for moderate yield goal i.e., N-P-K-S-B @ 100-27-35-18-1 kg/ha, and $b$ ) high management (integrated)- fertilizer nutrients for high yield goal i.e., N-P-K-S-Zn-B-Cowdung @ 120-33-60-22.5-4-1-10,000 kg/ha with Furadan 5G and Tilt 250 EC were as the main plots. The sub-plots were assigned to three 
varieties viz., Sufi, Shatabdi, and Prodip, and five seed rates viz., 80, 100, 120, 140 , and $160 \mathrm{~kg} / \mathrm{ha}$ were assigned to the sub-sub plots. Unit plot size was $3 \mathrm{~m} \times$ $4 \mathrm{~m}$. Seed size (according to 1000-grain weight) of these varieties were 35-40, 4146, and 53-58 g, representing small, medium bold and bold grain, respectively. Two-thirds of N-fertilizer and full amount of other fertilizers were applied as basal and the rest of $\mathrm{N}$-fertilizer was applied at 19 days after sowing (DAS). In high management treatment, well-decomposed cowdung was spread one week before sowing, Furadan 5G was applied @ 30 kg/ha before sowing and Tilt 250 EC was sprayed @ 1 L/ha before anthesis (70 DAS) and at grain filling stage (85 DAS). Seeds were sown on 2 December 2004 at the rate in accordance with the treatments. Prior to sowing, seeds were treated with a systemic fungicide Vitavax-200. Two irrigations were applied at 19 and 61 DAS. Weeds were controlled by spraying 2,4-D amine at 30 DAS.

Plant population and tiller production were recorded at 10 and 39 DAS, respectively. Lodging percentage was recorded at 87 DAS by visual observation. The disease Bipolaris leaf blight (BpLB) was assessed during grain filling stage (90 DAS) for each plot following the double-digit (00-99) scale of Saari and Prescott (1975). The first digit $\left(D_{1}\right)$ indicates the disease progress in height (vertical disease progress), and the second digit $\left(\mathrm{D}_{2}\right)$ refers to severity measured as the diseased leaf area. The percentage of disease severity was estimated according to the following formula (Sharma and Duveiller, 2003). \% disease severity $=\left(D_{1} / 9\right) \times\left(D_{2} / 9\right) \times 100$.

Number of days required for physiological maturity was recorded. Spike density, plant height and spike length were recorded at physiological maturity. Other yield contributing characters and grain (adjusted to 12\% moisture) and biomass (sun-dried) yields were recorded after harvesting. The data were analyzed statistically and means were compared by Duncan's Multiple Range Test (DMRT). Benefit-cost ratio (BCR) was calculated based on market price during the experimentation period.

\section{Results and Discussion}

Plant characters, yield and yield attributes as affected by management, variety and seed rate: Management effect was significant on tiller number per unit area, 1000-grain weight, and grain yield (Table 2). Significantly higher number of tillers resulted in remarkably higher number of spikes per unit area in high management. Significantly higher (18.4\%) grain yield was obtained from high management with higher 1000-grain weight. Plant population was dependent on the seed size i.e., number of plants per unit area was higher in a variety, which had smaller seed, and obviously it increased with the increase in seed rate (Table 2). Number of tillers per unit area was found higher in Shatabdi and lower in Prodip, and it also increased with the increase in seed rate upto 140 $\mathrm{kg} / \mathrm{ha}$. The increasing rate of tillers per unit area was less compared to 
Table 2. Grain yield, yield attributes and some other characters of wheat as influenced by management, variety, and seed rate.

\begin{tabular}{|c|c|c|c|c|c|c|c|c|c|c|c|}
\hline Treatments & $\begin{array}{c}\text { Plant } \\
\text { population }\end{array}$ & $\begin{array}{l}\text { No. of } \\
\text { tillers } / \mathrm{m}^{2}\end{array}$ & $\begin{array}{l}\text { Days to } \\
\text { physiolo- } \\
\text { gical } \\
\text { maturity }\end{array}$ & $\begin{array}{l}\text { Plant } \\
\text { height } \\
(\mathrm{cm})\end{array}$ & $\begin{array}{l}\text { No. of } \\
\text { spikes/ } \\
\mathrm{m}^{2}\end{array}$ & $\begin{array}{l}\text { Spike } \\
\text { length } \\
(\mathrm{cm})\end{array}$ & $\begin{array}{c}\text { No. of } \\
\text { spikelets/ } \\
\text { spike }\end{array}$ & $\begin{array}{l}\text { No. of } \\
\text { grains/ } \\
\text { spike }\end{array}$ & $\begin{array}{l}100- \\
\text { grain } \\
\text { wt (g) }\end{array}$ & $\begin{array}{l}\text { Grain } \\
\text { yield } \\
\text { (t/ha) }\end{array}$ & $\begin{array}{l}\text { Biomass } \\
\text { yield (t/ha) }\end{array}$ \\
\hline \multicolumn{12}{|l|}{ Management } \\
\hline $\mathrm{M}_{1}$ & 199 & $417 b$ & 100 & 101 & 304 & 11.1 & 18.8 & 52.0 & 47.lb & $3.81 b$ & 9.24 \\
\hline $\mathrm{M}_{2}$ & 206 & $484 a$ & 101 & 102 & 321 & 11.3 & 19.0 & 52.4 & $48.6 \mathrm{a}$ & $4.51 \mathrm{a}$ & 10.88 \\
\hline F-test & ns & $* *$ & ns & ns & ns & ns & ns & ns & $*$ & $*$ & ns \\
\hline CV (\%) & 18.38 & 4.14 & 2.42 & 2.05 & 6.75 & 2.57 & 4.31 & 7.33 & 2.67 & 18.56 & 22.34 \\
\hline \multicolumn{12}{|l|}{ Variety } \\
\hline Sufi (35-40) & $228 \mathrm{a}$ & $456 \mathrm{~b}$ & $98 \mathrm{~b}$ & 103 a & 338 a & $10.8 \mathrm{~b}$ & $19.6 \mathrm{a}$ & 59.9 a & $40.1 \mathrm{c}$ & $3.93 \mathrm{~b}$ & 9.99 b \\
\hline Shatabdi(41-46) & $213 b$ & 528a & $104 a$ & l0lb & $318 b$ & $10.4 \mathrm{c}$ & $17.5 b$ & $47.8 \mathrm{~b}$ & $45.9 \mathrm{~b}$ & $4.27 \mathrm{a}$ & 10.75 a \\
\hline Prodip (53-58) & $167 \mathrm{c}$ & $367 c$ & $99 \mathrm{~b}$ & $99 \mathrm{c}$ & 282 c & $12.4 \mathrm{a}$ & $19.6 \mathrm{a}$ & $48.9 \mathrm{~b}$ & $57.5 \mathrm{a}$ & $4.27 \mathrm{a}$ & $9.43 \mathrm{c}$ \\
\hline F-test & $* *$ & $* *$ & $* *$ & $* *$ & $* *$ & $* *$ & $* *$ & ** & $* *$ & $* *$ & ** \\
\hline CV (\%) & 9.90 & 13.74 & 1.69 & 2.29 & 6.71 & 4.44 & 6.15 & 6.76 & 4.74 & 5.48 & 7.60 \\
\hline \multicolumn{12}{|l|}{ Seed rate (kg/ha) } \\
\hline 80 & $135 \mathrm{e}$ & $364 \mathrm{~d}$ & $101 \mathrm{a}$ & 101 & $267 \mathrm{~d}$ & $11.4 \mathrm{a}$ & $19.3 \mathrm{a}$ & $53.6 \mathrm{a}$ & $48.4 \mathrm{a}$ & $4.03 \mathrm{~b}$ & $9.73 \mathrm{~b}$ \\
\hline 100 & $174 d$ & $435 c$ & lola & 102 & $303 c$ & 11.3ab & 19.2ab & $52.9 \mathrm{a}$ & $48.3 \mathrm{a}$ & $4.20 \mathrm{ab}$ & $9.99 \mathrm{ab}$ \\
\hline 120 & $202 c$ & $467 b$ & 10la & 102 & $324 b$ & 11.2abc & 18.8abc & 52.lab & $47.6 \mathrm{~b}$ & $4.26 \mathrm{a}$ & $10.35 \mathrm{a}$ \\
\hline 140 & $236 b$ & $494 a$ & $100 \mathrm{~b}$ & 101 & $340 a$ & $11.0 \mathrm{bc}$ & $18.7 \mathrm{bc}$ & $51.7 \mathrm{ab}$ & $47.6 \mathrm{~b}$ & $4.27 \mathrm{a}$ & $10.20 \mathrm{a}$ \\
\hline 160 & $267 a$ & $491 \mathrm{a}$ & 100b & 101 & $330 \mathrm{ab}$ & $10.9 c$ & $18.5 \mathrm{c}$ & $50.6 \mathrm{~b}$ & $47.4 \mathrm{~b}$ & $4.02 b$ & $10.02 \mathrm{ab}$ \\
\hline F-test & $* *$ & $* *$ & $* *$ & ns & $* *$ & $* *$ & $*$ & $* *$ & $* *$ & $* *$ & $*$ \\
\hline CV (\%) & 6.88 & 6.78 & 0.87 & 1.58 & 7.05 & 3.78 & 4.13 & 4.76 & 2.06 & 6.19 & 5.48 \\
\hline
\end{tabular}

Figures in the parentheses indicate 1000-grain weight (g) of the variety.

** and ns; significant at 5 and $1 \%$ level of probability, and not significant, respectively.

Within a column, for a factor, the figures having same letter(s) do not differ significantly at 5\% level of probability by DMRT.

$\mathrm{M}_{1}$ (medium management): 100-27-35-18-1 kg N-P-K-S-B/ha

$\mathrm{M}_{2}$ (high management): 120-33-60-22.5-4-1-10,000 kg N-P-K-S-Zn-B-Cowdung/ha with Furadan 5 G and Tilt 250 EC @ 30 kg and 2 L/ ha, respectively. 
increasing rate of plant population. Number of spikes per unit area was found higher in Sufi and lower in Prodip, and it also increased with the increase in seed rate upto $140 \mathrm{~kg} / \mathrm{ha}$ and the increasing rate of spikes per unit area was less compared to increasing rate of plant population. This trend indicates that in higher seed rates competition among the plants started before maximum tillering stage, which was manifested in low increase in tiller and spike production. Sarker et al. (2007) reported similar trend.

Among the varieties, Shatabdi was found late maturing compared to Sufi and Prodip (Table 2). The variety Sufi was taller than other varieties, but seed rate did not affect the plant height significantly. Prodip produced the longest spike among the varieties. Seed rate more than $120 \mathrm{~kg} / \mathrm{ha}$ significantly reduced the spike length. Number of spikelets per spike was found higher in Sufi and Prodip compared to Shatabdi and it decreased with the increase in seed rate. Sufi produced significantly higher number of grains per spike than other varieties, but the number of grains per spike decreased gradually with the increase in seed rate. Thousand-grain weight was the highest in Prodip, while the lowest 1000-grain weight was recorded in Sufi. Seed rate more than $100 \mathrm{~kg} /$ ha significantly reduced 1000-grain weight. Grain yields were similar in Shatabdi and Prodip but higher than Sufi. Almost similar variations in grain yields, 1000-grain weight, and other yield components were observed among the varieties Shatabdi, Prodip, and Sufi in different trials (WRC, 2005; 2006). The variety Sufi failed to produce higher grain yield due to its smaller grain size despite having higher number of spikes per unit area and grains per spike. Even with lower number of spikes per unit area, variety Prodip produced higher grain yield due to its bolder grain size. Although the highest grain yield was obtained at the seed rate of $140 \mathrm{~kg} / \mathrm{ha}$ the yield advantage over $120 \mathrm{~kg} / \mathrm{ha}$ was only $10 \mathrm{~kg} / \mathrm{ha}$. In Pakistan, where duration of winter is longer than Bangladesh, higher grain yield was obtained with a seed rate of $100 \mathrm{~kg} / \mathrm{ha}$ (Khan, 2003). Total biomass yield was highest in Shatabdi and lowest in Prodip. Higher biomass production in Shatabdi compared to different varieties and advanced breeding lines were also recorded (WRC, 2005; 2006). Total biomass production was almost similar with the seed rates from 100 to 160 $\mathrm{kg} / \mathrm{ha}$. In higher seed rates, higher number of plants and tillers failed to produce higher biomass yield.

Interaction effect of management and variety: In medium management (without Tilt), disease (BpLB) severity was less in Shatabdi compared to other varieties (Table 3). It indicates that this variety has resistance to BpLB to some extent. Relatively low BpLB severity in Shatabdi compared to other two varieties was also observed in field-testing under artificially inoculated condition (WRC, 2004). Spraying of Tilt reduced the disease significantly in all the varieties. Reduction of disease severity was higher in Prodip and Shatabdi than in Sufi. High management enhanced lodging remarkably in Sufi and slightly in Shatabdi, 
but the variety Prodip was completely free from lodging in both the managements. Lower disease reduction in Sufi under high management might be due to remarkably higher percentage of lodging (Table 3), which creates high humidity and warm temperature in the crop canopy favouring disease development and reducing fungicidal efficacy and spray efficiency. Under high management, significantly higher grain yield was obtained from Prodip and Shatabdi than from Sufi. In medium management, all the varieties produced similar but significantly lower grain yields.

Table 3. Interaction effect of management and variety on disease severity, lodging, yield and yield contributing characters of wheat.

\begin{tabular}{l|l|c|c|c|c|c|c|c}
\hline Management & Variety & $\begin{array}{c}\text { Disease } \\
\text { severity } \\
(\%)\end{array}$ & $\begin{array}{c}\text { Lodging } \\
(\%)\end{array}$ & $\begin{array}{c}\text { Number } \\
\text { of } \\
\text { tillers/ } \\
\mathrm{m}^{2}\end{array}$ & $\begin{array}{c}\text { Number } \\
\text { of } \\
\text { spikes/ } \\
\mathrm{m}^{2}\end{array}$ & $\begin{array}{c}\text { Number } \\
\text { of } \\
\text { grains/ } \\
\text { spike }^{1}\end{array}$ & $\begin{array}{c}1000- \\
\text { grain } \\
\text { wt } \\
(\mathrm{g})\end{array}$ & $\begin{array}{c}\text { Grain } \\
\text { yield } \\
\text { (t/ha) }\end{array}$ \\
\hline $\mathrm{M}_{1}$ & Sufi & $26.1 \mathrm{a}$ & 6.68 & 425 & 327 & 59.6 & 39.4 & $3.73 \mathrm{c}$ \\
& Shatabcli & $20.2 \mathrm{~b}$ & 0.00 & 472 & 310 & 47.7 & 45.9 & $3.87 \mathrm{c}$ \\
& Prodip & $26.7 \mathrm{a}$ & 0.00 & 353 & 276 & 48.7 & 56.1 & 3.83 \\
& & & & & & & & $\mathrm{C}$ \\
\hline $\mathrm{M}_{2}$ & Sufi & $18.8 \mathrm{~b}$ & 15.73 & 488 & 349 & 60.1 & 40.8 & $4.14 \mathrm{~b}$ \\
& Shatabdi & $10.9 \mathrm{c}$ & 1.47 & 584 & 326 & 47.8 & 45.9 & $4.68 \mathrm{a}$ \\
& Prodip & $11.8 \mathrm{c}$ & 0.00 & 381 & 289 & 49.2 & 59.0 & $4.72 \mathrm{a}$ \\
\hline F-test & & $*$ & $\mathrm{nS}$ & $\mathrm{ns}$ & $\mathrm{ns}$ & $\mathrm{flS}$ & $\mathrm{fls}$ & $* *$ \\
$\mathrm{CV}(\%)$ & & - & - & 13.74 & 6.71 & 6.76 & 4.74 & 5.48 \\
\hline
\end{tabular}

*, **, and ns; significant at 5 and $1 \%$ level of probability, and not significant, respectively. Within a column, the figures having same letter(s) do not differ significantly at $5 \%$ level of probability by DMRT.

Percentage data were transformed by square root (for disease severity) and arc sine (for lodging) transformation method before analysis.

$\mathrm{M}_{1}$ (medium management): 100-27-35-18-1 kg N-P-K-S-B/ha

$\mathrm{M}_{2}$ (high management): 120-33-60-22.5-4-1-10,000 kg N-P-K-S-Zn-B-Cowdung/ha with Furadan 5G and Tilt 250 EC @ 30 kg and 2 L/ha, respectively.

Interaction effect of management and seed rate: There was an increasing trend in tiller production with the increase in seed rate under high management (Table 4). In medium management, tiller number increased upto the seed rate of 140 $\mathrm{kg} / \mathrm{ha}$ and then decreased. Therefore, competition among tillers in higher seed rate began earlier in medium management than in high management. Similar trend was observed in spike number per unit area. 
Table 4. Interaction effect of management and seed rate on disease severity, lodging, yield and yield contributing characters of wheat.

\begin{tabular}{l|c|c|c|c|c|c|c|c}
\hline Management & $\begin{array}{c}\text { Seed } \\
\text { rate } \\
(\mathrm{kg} / \mathrm{ha})\end{array}$ & $\begin{array}{c}\text { Disease } \\
\text { severity } \\
(\%)\end{array}$ & $\begin{array}{c}\text { Lodging } \\
(\%)\end{array}$ & $\begin{array}{c}\text { No. of } \\
\text { tillers/ } \\
\mathrm{m}^{2}\end{array}$ & $\begin{array}{c}\text { No. of } \\
\text { spikes/ } / \\
\mathrm{m}^{2}\end{array}$ & $\begin{array}{c}\text { No. of } \\
\text { grains/ } \\
\text { spike }\end{array}$ & $\begin{array}{c}100- \\
\text { grain } \\
\text { wt (g) }\end{array}$ & $\begin{array}{c}\text { Grain } \\
\text { yield } \\
\text { (t/ha })\end{array}$ \\
\hline $\mathrm{M}_{1}$ & 80 & 23.6 & 0.03 & $349 \mathrm{f}$ & 258 & 53.9 & 47.8 & 3.69 \\
& 100 & 23.3 & 0.00 & $380 \mathrm{e}$ & 287 & 52.4 & 47.5 & 3.81 \\
& 120 & 24.6 & 0.00 & $437 \mathrm{~d}$ & 319 & 52.1 & 46.7 & 4.08 \\
& 140 & 25.4 & 6.11 & $462 \mathrm{~cd}$ & 339 & 51.4 & 47.1 & 3.81 \\
\hline $\mathrm{M}_{2}$ & 160 & 24.7 & 5.00 & $455 \mathrm{~d}$ & 319 & 50.2 & 46.6 & 3.64 \\
\hline & 10 & 13.9 & 0.56 & $379 \mathrm{e}$ & 275 & 53.4 & 49.0 & 4.37 \\
& 100 & 12.5 & 3.56 & $490 \mathrm{bc}$ & 319 & 53.4 & 49.1 & 4.58 \\
& 120 & 13.4 & 4.11 & $497 \mathrm{~b}$ & 329 & 52.6 & 48.6 & 4.61 \\
& 140 & 14.3 & 5.78 & $526 \mathrm{a}$ & 342 & 51.6 & 48.1 & 4.61 \\
& 160 & 15.0 & 14.67 & $528 \mathrm{a}$ & 342 & 50.9 & 48.1 & 4.39 \\
\hline F-test & & $\mathrm{ns}$ & $\mathrm{ns}$ & $* *$ & $\mathrm{~ns}$ & $\mathrm{~ns}$ & $\mathrm{~ns}$ & $\mathrm{~ns}$ \\
\hline & & - & - & 6.78 & 7.05 & 4.76 & 2.06 & 6.19 \\
\hline
\end{tabular}

** and ns; significant at $1 \%$ level of probability and not significant, respectively.

Within a column, the figures having same letter(s) do not differ significantly at $5 \%$ level of probability by DMRT.

Percentage data were transformed by square root (for disease severity) and arc sine (for lodging) transformation method before analysis.

$\mathrm{M}_{1}$ (medium management): 100-27-35-18-1 kg N-P-K-S-B/ha

$\mathrm{M}_{2}$ (high management): 120-33-60-22.5-4-1-10,000 kg N-P-K-S-Zn-B-Cowdung/ha with Furadan 5G and Tilt 250 EC @ 30 kg and 2 L/ha, respectively.

Interaction effect of variety and seed rate: Lodging was higher in variety Sufi and it increased with the increase in seed rate (Table 5). Very little tendency of lodging was found in variety Shatabdi, while lodging was not at all observed in Prodip. Tolerance to lodging in Prodip was also observed in different field experiments conducted by WRC (WRC, 2005; 2006). Strong and stout stem, relatively short phenotype and erect plant type might have contributed to lodging tolerance in this variety. Significantly higher number of tillers per unit area was found in Shatabdi at higher seed rates. Prodip produced significantly lower number of tillers. In all the three varieties, number of tillers increased with the increase in seed rate except in Shatabdi at $160 \mathrm{~kg} / \mathrm{ha}$. It indicated that competition among tillers in the variety Shatabdi started earlier at higher seed rate because of its high tillering ability. 
Table 5. Interaction effect of variety and seed rate on disease severity, lodging, yield and yield contributing characters of wheat.

\begin{tabular}{l|l|l|l|l|l|l|l|l}
\hline \multicolumn{1}{c|}{ Variety } & $\begin{array}{c}\text { Seed } \\
\text { rate } \\
(\mathrm{kg} / \mathrm{ha})\end{array}$ & $\begin{array}{c}\text { Disease } \\
\text { severity } \\
(\%)\end{array}$ & $\begin{array}{c}\text { Lodging } \\
(\%)\end{array}$ & $\begin{array}{c}\text { No. of } \\
\text { tillers/ } \\
\mathrm{m}^{2}\end{array}$ & $\begin{array}{c}\text { No. of } \\
\text { spikes/ } \\
\mathrm{m}^{2}\end{array}$ & $\begin{array}{c}\text { No. of } \\
\text { grains/ } \\
\text { spike }\end{array}$ & $\begin{array}{c}100- \\
\text { grain } \\
\text { wt (g) }\end{array}$ & $\begin{array}{c}\text { Grain } \\
\text { yield } \\
\text { (t/ha) }\end{array}$ \\
\hline Sufi & 80 & 22.0 & $0.88 \mathrm{~cd}$ & $357 \mathrm{fgh}$ & 273 & 61.8 & 40.7 & 3.91 \\
& 100 & 21.2 & $2.83 \mathrm{~cd}$ & $440 \mathrm{~cd}$ & 325 & 60.7 & 40.3 & 4.07 \\
& 120 & 22.0 & $6.17 \mathrm{c}$ & $456 \mathrm{c}$ & 349 & 58.0 & 40.2 & 4.06 \\
& 140 & 23.9 & $17.00 \mathrm{~b}$ & $507 \mathrm{~b}$ & 373 & 61.5 & 39.9 & 3.94 \\
& 160 & 23.0 & $29.17 \mathrm{a}$ & $522 \mathrm{~b}$ & 371 & 57.4 & 39.4 & 3.71 \\
\hline Shatabdi & 80 & 15.0 & $0.00 \mathrm{~d}$ & $409 \mathrm{de}$ & 275 & 48.6 & 46.3 & 4.05 \\
& 100 & 14.6 & $2.50 \mathrm{~cd}$ & $516 \mathrm{~b}$ & 307 & 49.0 & 46.5 & 4.31 \\
& 120 & 15.2 & $0.00 \mathrm{~d}$ & $560 \mathrm{a}$ & 331 & 47.8 & 45.3 & 4.56 \\
& 140 & 16.9 & $0.83 \mathrm{~cd}$ & $593 \mathrm{a}$ & 346 & 46.3 & 45.9 & 4.25 \\
& 160 & 15.8 & $0.33 \mathrm{~cd}$ & $562 \mathrm{a}$ & 330 & 47.2 & 45.6 & 4.21 \\
\hline Prodip & 80 & 19.1 & $0.00 \mathrm{~d}$ & $326 \mathrm{~h}$ & 251 & 50.6 & 58.3 & 4.14 \\
& 100 & 17.9 & $0.00 \mathrm{~d}$ & $350 \mathrm{gh}$ & 277 & 49.1 & 58.1 & 4.24 \\
& 120 & 19.8 & $0.00 \mathrm{~d}$ & $384 \mathrm{efg}$ & 292 & 49.7 & 57.3 & 4.48 \\
& 140 & 18.7 & $0.00 \mathrm{~d}$ & $383 \mathrm{efg}$ & 302 & 48.2 & 56.9 & 4.36 \\
& 160 & $\mathrm{~ns}$ & $* *$ & $* *$ & $\mathrm{~ns}$ & $\mathrm{~ns}$ & $\mathrm{~ns}$ & $\mathrm{~ns}$ \\
\hline F-test & & - & - & 6.78 & 7.05 & 4.76 & 2.06 & 6.19 \\
CV(\%) & & & & & & & & \\
\hline
\end{tabular}

** and ns; significant at $1 \%$ level of probability and not significant, respectively.

Within a colunm, the figures having same letter(s) do not differ significantly at $5 \%$ level of probability by DMRT.

Percentage data were transformed by square root (for disease severity) and arc sine (for lodging) transformation method before analysis.

Interaction effect of management, variety and seed rate: In both the managements, higher severity of BpLB was observed in Sufi and Prodip than in Shatabdi (Table 6). Therefore, Shatabdi has some resistance to BpLB disease under field condition. A little higher disease severity was observed in higher seed rate, especially under medium management in Sufi and Shatabdi. Increase in disease severity at higher seed rate has also been reported by others (Singh et al., 1998), which might be due to higher plant density creating favourable microclimate for rapid development and spread of the disease. However, spraying of Tilt reduced the disease severity in all the varieties and higher reduction was obtained in Prodip. 
6. Interaction effect of management, variety and seed rate on disease severity.

\begin{tabular}{|c|c|c|c|c|c|c|}
\hline \multirow{3}{*}{$\begin{array}{c}\text { Seed rate } \\
(\mathrm{kg} / \mathrm{ha})\end{array}$} & \multicolumn{3}{|c|}{$\mathrm{M}_{1}$} & \multicolumn{3}{|c|}{$\mathrm{M}_{2}$} \\
\hline & Sufi & Shatabdi & Prodip & Sufi & Shatabdi & Prodip \\
\hline & \multicolumn{6}{|c|}{ Disease severity } \\
\hline 80 & $24.7 \mathrm{abc}$ & 18.9 de & $27.2 \mathrm{ab}$ & 19.3 de & $11.1 \mathrm{gh}$ & $11.1 \mathrm{gh}$ \\
\hline 100 & $24.7 \mathrm{abc}$ & 19.3 de & $25.9 \mathrm{ab}$ & 17.7 ef & $9.9 \mathrm{~h}$ & $9.9 \mathrm{~h}$ \\
\hline 120 & 24.7abc & 19.3de & $29.6 a$ & 19.3de & 11.lgh & $9.9 \mathrm{~h}$ \\
\hline 140 & $30.0 \mathrm{a}$ & 22.6bcd & 23.5bcd & 17.7ef & 11.lgh & $14.0 f g$ \\
\hline 160 & 26.3ab & 20.6cde & 27.2ab & 19.8de & 11.lgh & $14.0 \mathrm{fg}$ \\
\hline
\end{tabular}

*; significant at 5\% level of probability.

Figures having same letter(s) do not differ significantly at 5\% level of probability by DMRT.

Data were transformed by square root transformation method before analysis.

$\mathrm{M}_{1}$ (medium management): 100-27-35-18-1 kg N-P-K-S-B/ha

$\mathrm{M}_{2}$ (high management): 120-33-60-22.5-4-1-10,000 kg N-P-K-S-Zn-B-Cowdung/ ha with Furadan 5G and Tilt 250 EC @ 30 kg and 2 L/ha, respectively.

Although the interaction effect of managements, varieties, and seed rates was not significant on grain yield, apparently the highest yield was obtained from variety Prodip with $140 \mathrm{~kg} / \mathrm{ha}$ seed rate under high management (Table 7). Shatabdi and Sufi produced higher yield with 120 and $100 \mathrm{~kg} / \mathrm{ha}$ seed rate, respectively. In medium management, all the varieties produced higher yields with $120 \mathrm{~kg} / \mathrm{ha}$ seed rate. The yield advantage of Sufi at $120 \mathrm{~kg} / \mathrm{ha}$ seed rate over $100 \mathrm{~kg} / \mathrm{ha}$ was only $20 \mathrm{~kg} / \mathrm{ha}$. The benefit-cost ratio (BCR) in medium management was higher than in high management (Table 7). In each management and variety, where the grain yield was higher, the BCR was also higher except in Sufi in medium management. The variety Sufi gave higher BCR with $100 \mathrm{~kg}$ seed/ha. Therefore, seed rates of Sufi and Shatabdi might be 100 and $120 \mathrm{~kg} / \mathrm{ha}$, respectively, for both the managements, and that of Prodip might be 120 and $140 \mathrm{~kg} / \mathrm{ha}$ for medium and high management, respectively.

Since the initial plant population was similar in both the managements, it appeared that the effect of Furadan was insignificant (Table 2). This might be due to low insect population of the soil. Therefore, if Shatabdi were grown in high management without Furadan and Tilt, the BCR would have been high. Seed rate higher than $140 \mathrm{~kg} / \mathrm{ha}$ in medium management caused lower tiller and spike production per unit area, but the yields were higher at $120 \mathrm{~kg} / \mathrm{ha}$ in both the 
managements across all varieties (Table 4). Seed rate higher than $120 \mathrm{~kg} / \mathrm{ha}$ failed to produce higher yield due to lower number of grains per spike and lower 1000-grain weight (Table 2). Variety Prodip was more responsive to Tilt spray. In high management, Sufi produced lower yield than Shatabdi and Prodip, whereas similar yields were obtained from these varieties in medium management (Table 3). In both the managements, Sufi produced optimum yield with higher BCR at $100 \mathrm{~kg} / \mathrm{ha}$ seed rate, and the medium bold seeded Shatabdi produced higher yield with higher BCR at $120 \mathrm{~kg} \mathrm{ha}^{-1}$ seed rate (Table 7). The bolder seeded variety Prodip produced higher yields with higher BCR at 120 and $140 \mathrm{~kg} / \mathrm{ha}$ seed rates under medium and high management, respectively. This variety had higher severity of BpLB, higher disease reduction by applying Tilt, and complete resistance against lodging.

7. Interaction effect of management, variety and seed rate on grain yield (t/ha) and benefit-cost ratio (BCR) of wheat.

\begin{tabular}{|c|c|c|c|c|c|c|c|c|c|c|c|c|}
\hline \multirow{3}{*}{$\begin{array}{c}\text { Seed } \\
\text { rate } \\
(\mathrm{kg} / \mathrm{ha})\end{array}$} & \multicolumn{6}{|c|}{$\mathrm{M}_{1}$} & \multicolumn{6}{|c|}{$\mathrm{M}_{2}$} \\
\hline & \multicolumn{2}{|c|}{ Sufi } & \multicolumn{2}{|c|}{ Shatabdi } & \multicolumn{2}{|c|}{ Prodip } & \multicolumn{2}{|c|}{ Sufi } & \multicolumn{2}{|c|}{ Shatabdi } & \multicolumn{2}{|c|}{ Prodip } \\
\hline & Yield & BCR & Yield & BCR & Yield & BCR & Yield & BCR & Yield & BCR & Yield & BCR \\
\hline 80 & 3.64 & 3.21 & 3.60 & 3.20 & 3.83 & 3.33 & 4.17 & 2.17 & 4.49 & 2.34 & 4.45 & 2.27 \\
\hline 100 & 3.82 & 3.29 & 3.84 & 3.34 & 3.76 & 3.20 & 4.31 & 2.22 & 4.78 & 2.46 & 4.71 & 2.36 \\
\hline 120 & 3.84 & 3.26 & 4.24 & 3.61 & 4.17 & 3.48 & 4.27 & 2.17 & 4.87 & 2.47 & 4.79 & 2.37 \\
\hline 140 & 3.74 & 3.15 & 3.91 & 3.27 & 3.79 & 3.12 & 4.14 & 2.09 & 4.60 & 2.31 & 4.92 & 2.42 \\
\hline 160 & 3.59 & 2.97 & 3.77 & 3.10 & 3.57 & 2.91 & 3.82 & 1.94 & 4.65 & 2.31 & 4.71 & 2.28 \\
\hline
\end{tabular}

$\mathrm{M}_{1}$ (medium management): 100-27-35-18-1 kg N-P-K-S-B/ha

$\mathrm{M}_{2}$ (high management): 120-33-60-22.5-4-1-10,000 kg N-P-K-S-Zn-B-Cowdung/ha with Furadan

5G and Tilt250 EC @ 30 kg and 2 L/ha

Price of inputs:

$\mathrm{N}=$ Tk. $13.04 \mathrm{~kg}^{-1}, \mathrm{P}=$ Tk. $80.00 \mathrm{~kg}^{-1}, \mathrm{~K}=$ Tk. $28.00 \mathrm{~kg}^{-1}, \mathrm{~S}=\mathrm{Tk} .22 .22 \mathrm{~kg}^{-1}, \mathrm{Zn}=\mathrm{Tk}$. $239.00 \mathrm{~kg}^{-1}, \mathrm{~B}=$ Tk. $686.00 \mathrm{~kg}^{-1}$, Cowdung = Tk. $0.30 \mathrm{~kg}^{-1}$, Furadan $5 \mathrm{G}=$ Tk. $85.00 \mathrm{~kg}^{-1}$, Tilt 250 EC = Tk. $560.00(400 \mathrm{~m} 1)^{-1}, 2$, 4-D Amine $=$ Tk. $190.00(400 \mathrm{~m} 1)^{-1}$, Seed $=$ Tk. $16.00 \mathrm{~kg}^{-1}$, Ploughing (2) = Tk. 1,000.00 h${ }^{-1}$, Irrigation (2) = Tk. 1,000.00 ha-1, Spray of Tilt 250 EC (2) = Tk. 360.00 ha $^{-1}$ and Spray of 2, 4-D Amine (1) = Tk. $180.00 \mathrm{~h}^{-1}$, Labour (100) for fertilizer application, sowing, harvesting, threshing etc. = Tk. 6,000.00 h\&'.

Price of products:

Grain = TIc. $12.50 \mathrm{~kg} 1$ and Straw $=$ Tk. $1.00 \mathrm{~kg}^{-1}$. 


\section{Conclusion}

High management increased grain yield in all the varieties of wheat, but the response was higher in Shatabdi and Prodip than that of Sufi. The benefit-cost ratio was higher in medium management. The seed rates of Sufi and Shatabdi might be 100 and $120 \mathrm{~kg} / \mathrm{ha}$, respectively, for both the managements. Seed rates of Prodip might be 120 and $140 \mathrm{~kg} / \mathrm{ha}$ for medium and high management, respectively.

\section{References}

Ahmed, S. M. and C. A. Meisner. 1996. Wheat Research and Development in Bangladesh. Bangladesh Australia Wheat Improvement Project and CIMMYTBangladesh, Dhaka, Bangladesh. p. 201.

Ali, M. H. 1980. Effect of seed rate on yield of wheat. Bangladesh J. Agric. 5(1): 6-8.

BBS (Bangladesh Bureau of Statistics). 2005. Yearbook of Agricultural Statistics of Bangladesh, 2004. Bangladesh Bur. Stat., Stat. Div., Mini. Plan., Govt. People’s Repub. Bangladesh. p. 381.

Barma, N. C. D., P. K. Malaker, M. E. Baksh, I. Hossain, M. A. Samad, M. Saifuzzaman, M. A. Sufian and A. B. S. Hossain. 2006. Wheat Production in Bangladesh - an overview. In: Reynolds, M. P. and D. Gomez (eds.), Extended abstracts of the International Symposium on Wheat Yield Potential "Challenges to International Wheat Breeding”, March 20-24, 2006 Cd. Obregon, Mexico. CIMMYT, Mexico, D F. p. 49.

Gaffer, M. A. and S. M. A. Rahman. 1979. Effects of nitrogen, phosphorus and potassium and seeding methods on wheat. Bangladesh J. Agric. 4(1): 94.

Islam, M. S., M. A. Sattar, M. M. Rahman, M. A. Qayum, M. S. Alam and R. A. Mustafi (eds). 2004. Krishi Projukti Hatboi (Handbook on Agro-technology), 3rd Ed. Bangladesh Agricultural Research Institute, Gazipur- 1701, Bangladesh. p. 560. (In Bangla).

Khan, M. A. 2003. Wheat crop management for yield maximization. 1st ed. Wheat Research Institute, Faisalabad 38950, Pakistan. p. 94.

Razzaque, M. A., M. A. Sattar, M. S. Amin, M. A. Qayum and M. S. Alam (eds). 2000. Krishi Projukti Hathoi (Handbook on Agro-technology), 2nd Ed. Bangladesh Agricultural Research Institute, Gazipur-1701, Bangladesh. p. 464. (In Bangla).

Saari, E. B. and J. M. Prescott. 1975. A scale for appraising the foliar intensity of wheat disease. Plant Dis. Report. 59: 377-380.

Sarker, M. A. Z., P. K. Malaker, M. Saifuzzaman and D. B. Pandit. 2007. Effect of variety and seed rate on the yield of wheat. Bangladesh J. Agric. Environ. 3: 75-82.

Saunders, D. A. 1990. Report of an on-farm survey, Dinajpur District: Farmers' practices and problems, and their implications. Monograph No. 6. Wheat Research Centre, BARI, Nashipur, Dinajpur. p. 38. 
Sharma, R. C. and B. Duveiller. 2003. Selection index for improving Helminthosporium leaf blight resistance, maturity, and kernel weight in spring wheat. Crop Sc. 43: 2031-2036.

Singh, R. V., A. K. Singh, R. Abmed and S. P. Singh. 1998. Influence of agronomic practice on foliar blight and identification of alternate hosts in the rice-wheat cropping system. In: B. Duveiller, H. J. Dubin, J. Reeves and A. McNab, (eds.), Helminthosporium Blights of Wheat: Spot Blotch and Tan Spot. CIMMYT, Mexico, D F. pp. 346-348.

WRC (Wheat Research Centre). 2004. Annual Report. Wheat Research Centre, Bangladesh Agricultural Research Institute, Dinajpur 5200, Bangladesh. p. 105.

WRC (Wheat Research Centre). 2005. Annual Report. Wheat Research Centre, Bangladesh Agricultural Research Institute, Dinajpur 5200, Bangladesh. p. 146.

WRC (Wheat Research Centre). 2006. Annual Report. Wheat Research Centre, Bangladesh Agricultural Research Institute, Dinajpur 5200, Bangladesh. p. 113. 